ISSN: 2224-0616

Int. J. Agril. Res. Innov. Tech. 11(1): 60-68, June 2021

DOI: https://doi.org/10.3329/ijarit.v11i1.54467

\section{OPEN 2 ACCESS}

Available online at https://ijarit.webs.com https://www.banglajol.info/index.php/IJARIT

\title{
Evaluation and demonstration of leguminous shrubs hedgerows intercropping with maize crop
}

\author{
B. Lemage*, M. Tsegaye and Y. Anmaw \\ Received 10 March 2021, Revised 17 May 2021, Accepted 23 June 2021, Published online 30 June 2021
}

\begin{abstract}
A B S T R A C T
Smallholder farmers influenced from the challenges of production constraints to afford farm family with surplus food. To improve this problem the present study was designed to evaluate legume shrubs hedgerow intercropping with maize. In the present study, the growth performance of Sesbania sesban and Cajanus cajan was evaluated to determine their potential in hedgerow intercropping. The result revealed that Sesbania sesban performs better than Cajanus cajan in terms of biomass provision in the successive pruning, mean height, branching, diameter at breast height and root collar diameter. Biomass produced from Sesbania sesban was significantly higher than Cajanus cajan, this plays great role in soil nutrient improvement and maize yield also increased. There was an increasing trend in soil properties in terms of organic $\mathrm{C}$, total $\mathrm{N}$, in legume treatments especially in Sesbania sesban hedgerow to the initial and control soils. Maize grain yield higher under Sesbania sesban hedgerow plot than Cajanus cajan, maize with fertilizer and control. This should be intensively demonstrated to sustain the agricultural production as an organic farming through integration of easily adapting, less competing with the companion crop, deep rooted and fast growing legume tree/shrub species. Further research is important in areas of determining decomposing rate of different parts, pruned biomass and potential species should be identified.
\end{abstract}

Keywords: Biomass incorporation, Cajanus cajan, Legume shrubs, Sesbania sesban.

Southern Agricultural Research Institute, Jinka Agricultural Research Center, P.O. Box 96 Jinka, Ethiopia

*Corresponding author’s email: belaynehlemage@gmail.com (Belayneh Lemage)

Cite this article as: Lemage, B., Tsegaye, M. and Anmaw, Y. 2021. Evaluation and demonstration of leguminous shrubs hedgerows intercropping with maize crop. Int. J. Agril. Res. Innov. Tech. 11(1): 60-68. https://doi.org/10.3329/ijarit.v11i1.54467

\section{Introduction}

In many parts of the tropics and predominantly in tropical Africa, nitrogen $(\mathrm{N})$ is the most limiting nutrient to crop production. Supply of balanced nutrients to the soil is essential to get desired crop yield. $\mathrm{N}$ is essential for the growth of plants and when its supply is inadequate, young plant will fail to establish while established plant will become declining (Richards et al., 1993; Assefa et al., 2013). Costs of inorganic fertilizers limit their use in adequate quantities by most smallholder farmers. This has led to increased interest in development of integrated soil fertility management systems that incorporate woody species into crop production systems where leafy biomass provides $\mathrm{N}$ to the annual crop (Kang et al., 1990). Low soil fertility is the major cause for low agricultural productivity, food insecurity, low income and poverty in Ethiopia (Abebe et al., 2006). Much of the decline in soil quality is linked to human population growth and organic matter loss due to intensive cultivation. Loss of soil quality is explained through increased bulk density, reduced inorganic matter content and availability of soil nutrients. Obviously, substantial increase of yield will result in correcting soil nutrient deficiencies using different experimentally supported methods. Maintenance of soil quality is considered essential for ensuring sustainable land use; and land resource management must aim at soil conservation (Parysow et al., 2001).

In tropical Africa, nitrogen is the most limiting nutrient to crop production; high costs of inorganic fertilizers limit their use in sufficient quantities by most smallholder farmers. This has led to increased interest in development of integrated soil fertility management systems that incorporate woody species into crop production systems where leafy biomass provide $\mathrm{N}$ to the annual crop. Trees and shrubs are used in 
hedgerow intercropping cropland or parkland systems, improved fallows and shaded perennialcrop systems. Large amounts of $\mathrm{N}$ and moderate amounts of $\mathrm{P}$ have been observed in standing biomass, but much variation occurs in the recycling of these nutrients. However, leguminous trees species have shown some potential for soil fertility improvement through biomass transfer, short term fallows, nitrogen fixation, re-activation of the ' $\mathrm{N}$ bulge' and phosphorus scavenging (Hartemink et al., 2000). Agroforestry practices are based on the idea that trees increase nutrient cycling, improve soil fertility, and support the growth of crops (Nair et al., 1999). Agroforestry can be a viable option to alleviate degradation and loss of soil fertility from the agricultural fields. Agroforestry, especially alley cropping, can help more efficiently to manage agriculture production system (Jordan, 2004). Trees continuously contribute to soil organic matter through shedding of leaves and roots. High decomposition and mineralization rates under woody species as compared to the open field are due to improved soil conditions under a tree canopy. In this respect, the relatively high organic matter content under a tree canopy is a key factor (Young, 1999). Tree pruning are used as mulch to suppress weeds, green manure, firewood as well as browse. Leguminous trees fixed nitrogen biologically to companion crops (USDA, 2012).

Alley cropping is a new step because the trees are used primarily for soil improvement. Alley cropping is one of an important agroforestry practice in which high organic biomass produced from the pruning's of hedgerow species and build soil organic matter constituted with beneficial soil nutrients. In alley cropping, food or fodder crops are grown between hedgerows species. In this system, arable crops are grown in between the hedges of woody species, preferably legumes, that are regularly cut back to minimize the competition between tree and crop for light, water and nutrients (Tossah el al., 1998). By combining deep rooting trees with shallow rooting crops, alley cropping systems use resources more efficiently than mono-cropping systems. While alley cropping has been widely promoted in the tropics as an option for subsistence farmers (Nair et al., 1999).

In Ethiopia, agricultural production system is intensively monoculture, either in large scale or in small-scale farmlands. The productivity declines from time to time due to soil fertility loss and insufficient supply of plant nutrients. The tradition of agricultural production in small-scale farm faces a series of challenges, specifically the mineral fertilizer application due to its cost and affordability problem. To address this problem, agroforestry practices may play an important role for a sustainable agricultural production and soil fertility improvement; due to its ecological ad economic feasibility. This study intended to evaluate the potential legume shrubs on maize yield and soil fertility improvement in alley cropping through hedgerows of legume shrub species.

\section{Objectives}

- To evaluate shrubs biomass under hedgerow management and to what extent its biomass maintain maize yield on local soils

- To evaluate the effects of shrubs on soil improvement and crop yield variations.

\section{Expected output}

The better contributing legume shrub for soil fertility improvement and maize yield enhancement on agricultural lands under alley cropping was identified. The main aim of this study was to identify the important legume shrub's contribution on soil nutrient addition on agricultural land, as well as transferred biomass benefit on maize yield increment.

\section{Materials and Methods}

\section{Study area description}

The experiment was carried out from March 2017 to August 2019 at Kayisa kebele farmers training center (FTC) in Debub Ari district of South Omo Zone. The study site has a bi-modal rainfall pattern with shorter rainy season from MarchMay, which is important for crop production and longest rainy season from August- November. It is located between $36^{\circ} 41^{\prime} \mathrm{E}$ and $05^{\circ} 50^{\prime} \mathrm{N}$. Biophysically, the area characterized as altitudinal ranges from 1435-2400 $\mathrm{m}$ above sea level, total annual rainfall is $1304.4 \pm 250.7 \mathrm{~mm}$. The annual mean minimum and maximum temperatures are $16.3 \pm 0.9^{\circ} \mathrm{C}$ and $27.7 \pm 1.4^{\circ} \mathrm{C}$ from Jinka station and the major soil texture of the area is sandy loam, with the percentage of 12, 10 and 78 for clay, silt and sand, respectively. The communities practicing mixed type of production system that means crop production and animal raring termed as agro pastoralists.

\section{Experimental design and treatments}

Completely randomized block design (RCBD) with three replications was used to conduct the experiment. The experiment was done on FTC at Kayisa Kebele in Debub Ari district. The treatments assigned for experimentation were maize grown between alley widths of Cajanus cajan (T1), maize grown between alley widths Sesbania sesban (T2), maize grown with inorganic fertilizer ( $\mathrm{T}_{3}$ ) and maize grown without any addition of inorganic fertilizer or organic amendments (T4). Double rows of legume 
shrubs were established on prepared agricultural land. The plot size required for this study was 10 $\mathrm{m} \times 10 \mathrm{~m}$, constructed to carry out the experimentation. Seeds of legume shrub species were directly sown on early prepared trail field with plant spacing of $50 \mathrm{~cm} \times 50 \mathrm{~cm}$ within and between shrubs row. The spacing between rows of maize and shrub was $75 \mathrm{~cm}$, and $75 \mathrm{~cm} \mathrm{x} 30 \mathrm{~cm}$ for maize within and between rows, respectively. Crop cultivation was done after 15 to 30 days of biomass transferring and incorporation.

\section{Growth performance}

Measurements of the growth parameters were done after full establishment and shrubs attain enough growth status to generate required data. Plant height, root collar diameter, diameter at breast height and branch number was determined on 10 randomly selected plants of each shrub species. In the present study, S. sesban and C. cajan species performance under alley cropping system attain promising growth. All desirable tending, periodical pruning and biomass transferring activities were done throughout the experimentation period. Pruning and biomass transferring has been undertaken prior to crop planting; it was attained to incorporate the pruned biomass and facilitation of the decomposition process.

\section{Collected data}

\section{Growth parameters}

All necessary management activities were done throughout the experimentation period. Activities like thinning, weeding, pruning, biomass transferring and incorporation, plowing and sowing annual crop/maize/ and fencing were done. For legume shrubs growth parameters like height, root collar diameter (above ground 10 $\mathrm{cm}$ ), DBH (diameter at breast height $1.3 \mathrm{~m}$ ), branch number, leafy biomass (including leaf and green branches) incorporated into soil and wood production data were collected during the experimentation period. On the other hand, maize crop data collection has carried out from the planting time to the harvesting stage. Collected data were time of planting, germination, plant height, number of ears, ear length total biomass, TSW and grain yield.

\section{Sample collection and nutrient analysis}

The legume species used have the potential of contributing decomposable biomass soil fertility improvement and capable of providing biomass after frequent pruning. These data were needed to evaluate hedgerow species effect on maize yield and potential of improving soil fertility in turn crop yield enhancement. Soil samples of each plot were collected before establishing hedgerows species and after intercropping or at the end of the experimentation period. The soil samples were randomly collected from $0-20 \mathrm{~cm}$ soil depth and bulked into a composite sample used before establishment. The plot based soil sample was taken at the end of the experimentation period to know the effect. The soil samples were air dried, grounded and sieved with $2 \mathrm{~mm}$ mesh for chemical analysis. The $\mathrm{pH}$ of the soil was measured in 1: 2.5 (soil: water ratio), soil organic carbon by Walkey and Black procedure (Nelson and Sommers, 1996), total nitrogen content of the soil was determined by wet-oxidation (wet digestion) procedure (Kjeldahl, 1883) and available P by using Bray II method (Bray and Kurtz, 1945). Potassium contents of the extract were determined with flame photometer, the available sulfur of soil can be done by the turbidymetric methods and extracted by calcium chloride dehydrate, the concentration of SO4-S can be read by spectrophotometer in $420 \mathrm{~nm}$ wave length. Soil texture was determined by hydrometer method (Day, 1965). On the other hand, leaf sample for each shrub species was collected to evaluate the nutrient composition, pruned of biomass produced in nutrient release after incorporation into the soil and to determine released nutrient with maize crop yield.

\section{Data analysis}

Shrubs growth performances parameters, biomass production, leaf nutrient parameters, soil parameters and maize yield and yield component data were computed by using SAS software. The means values of the parameters were compared using the least significant difference (LSD) at $5 \%$ level of significance using SAS statistical software (version 9.0) and for data organization Microsoft excel sheet was used.

\section{Results and Discussion}

\section{Growth performance of established legume shrubs}

The growth parameters presented on Table 1, 2 and 3 shows the performance evaluation in the successive growing period. The experiment conducted on effect of legume shrub species contribution on annual crop production under alley cropping practice, species growth performance evaluation was conducted with respect to different growth parameters during the experimentation period (Table 1, 2 and 3). The mean height, root collar diameter, DBH and number branches of Sesbania sesban was significantly higher than that Cajanus cajan used in the current study. The amount of leaf biomass (PM) produced from Sesbania sesban (11.56 ton ha $^{-1}$ ) was significantly higher than Cajanus cajan (3.20 ton ha $\mathrm{a}^{-1}$ ) in alley cropping system. This result is in line with finding of Sjögren et al. 
(2010), who reported that Sesbania sesban showed a very high growth potential in 6 and 18 months improved fallows conducted in Kenya. Biomass production in each cutting period resulted with different values, this due to certain factors related with the performance, time of establishment, frequency cutting and period at which pruning carried out. The biomass production is effected with different parameters, such as branch number, root collar diameter, DBH and the type the species used and tolerance to frequency of pruning.

Table 1. Growth performance parameters of the grown leguminous shrub species in hedgerows intercropping.

\begin{tabular}{|lcccc|} 
Legume Species used & \multicolumn{4}{c|}{ Measured parameters } \\
& $\mathrm{H}(\mathrm{m})$ & $\mathrm{RCD}(\mathrm{cm})$ & $\mathrm{DBH}(\mathrm{cm})$ & $\mathrm{BN}$ \\
\hline Cajanus cajan & $1.80^{\mathrm{b}}$ & $2.34^{\mathrm{b}}$ & $1.10^{\mathrm{b}}$ & $91.00^{\mathrm{b}}$ \\
\hline Sesbania sesban & $2.70^{\mathrm{a}}$ & $3.33^{\mathrm{a}}$ & $2.00^{\mathrm{a}}$ & $150.00^{\mathrm{a}}$ \\
\hline LSD & 0.839 & 0.910 & 0.840 & 51.200 \\
\hline CV (\%) & 29.20 & 24.85 & 42.80 & 33.00 \\
\hline
\end{tabular}

Source own data, 2017-2019

Means with the same letter are not significantly different within rows; where: $H$ (height), $B N$ (branch number), $D B H$ (diameter at breast height), LSD (least significant difference), CV (coefficient of variation)

Table 2. Biomass transferred at each cutting period on plots of legumes species.

\begin{tabular}{|l|c|c|}
\hline Cutting frequency & \multicolumn{2}{c|}{ Shrub species used } \\
\hline FRB & Cajanus cajan & Sesbania sesban \\
\hline SRB & $30.00 \mathrm{~kg}$ & $113.30 \mathrm{~kg}$ \\
\hline TRB & $23.90 \mathrm{~kg}$ & $87.00 \mathrm{~kg}$ \\
\hline Average & $42.10 \mathrm{~kg}$ & $146.50 \mathrm{~kg}$ \\
\hline
\end{tabular}

Source own data 2017-2019

Where FRC (first round biomass), SRB (second round biomass), TRB (third round biomass)

Table 3. Biomass production per hedgerow species grown in alley cropping system.

\begin{tabular}{|l|c|c|}
\hline Shrub species & \multicolumn{2}{c|}{ Biomass pruned and transferred } \\
\hline Cajanus cajan & $\mathrm{BM} \mathrm{kg} \mathrm{ha}^{-1}$ & BM ton ha-1 \\
\hline Sesbania sesban & $320 \mathrm{~h}^{\mathrm{b}}$ & $3.200^{\mathrm{b}}$ \\
\hline LSD & $11561^{\mathrm{a}}$ & $11.561^{\mathrm{a}}$ \\
\hline CV (\%) & 30.62 & 3.062 \\
\hline
\end{tabular}

Source own data, 2017-2019

Where BM (biomass), LSD (least significant difference), CV (coefficient of variation)

Table 4. Total biomass, leaf and wood biomass produced from hedgerow species.

\begin{tabular}{|l|c|c|c|c|}
\hline Shrub species & \multicolumn{3}{c|}{ Wood biomass and total biomass } \\
\hline Cajanus cajan & WBM kg ha ${ }^{-1}$ & WBM ton ha & LBM ton ha & TBM ton ha $^{-1}$ \\
\hline Sesbania sesban & 2750.00 & 2.75 & 3.20 & 6.00 \\
\hline
\end{tabular}

Source own data, 2017-2019

Where WBM (wood biomass), LBM (leaf biomass), TBM (total biomass)

Soil fertility improvement in hedgerow species

Hedgerows species restore some ecosystem functions to fields by increasing nutrient cycling and maintaining levels of soil organic matter. The result showed a variation in different soil physicochemical properties under alley cropping practice (Table 5, 6 and 7). Soil parameters were increased, but statistically no significant difference exist except in case of sulfur, it was significantly increased in hedges Sesbania as 
compared with the other treatments (Table 6). The soil nutrients contributed by $S$. sesban were OC, TN, P, B and S higher than that of C. cajan, none alley cropped plots and before planting (Table 5). Hedgerows species play an important role in soil nutrient improvement through large biomass addition. The result of this study in line with findings of Young (1999) who reported provision of plant available $\mathrm{N}$ from decomposing Sesbania biomass, increased soil organic matter, improved nutrient, water retention in the soil. Miah et al. (1997) observed higher soil pH and organic $\mathrm{C}$ in alley cropping system. Kwesiga et al. (1999) also reported Short-duration planted fallows using leguminous species replenish soil fertility and to increase subsequent maize yields at Eastern Zambia. Alley cropping helped to maintain soil fertility by increasing nutrient cycling and reducing leaching of nutrients (Chamshama et al., 1998). Evans et al. (2001) reported nitrogen accumulation had also been achieved by cutting materials from trees/ shrubs intentionally grown for green leaf manure production. Nutrients released from leaf determined by leaf biomass produced from legume species grown on experimentation site. $S$. sesban provides high leaf biomass compared with Pigeon pea and it plays important role in releasing beneficial nutrients to crop production. Leaf analysis result showed that the amount of nutrient concentration varies from species to species. The legume species improve the soil through biological nitrogen fixation where by recycled nutrients are deposited through litter or when pruned biomass was transferred. Decomposable biomass/Soil organic matter and organic carbon increased in alley cropping practice at the study site, this in line with the findings of Miller and Donahue (1990) who reported that SOM was major source of nutrients such as nitrogen, and available $\mathrm{P}$ and $\mathrm{K}$ in unfertilized soils. In addition, organic carbon is positively correlated with available $\mathrm{N}$ and $\mathrm{K}$ nutrients (Maiti and Ghose, 2005). Addition of green manure from hedgerows also improves soil physical qualities such as bulk density (Alegre and Rao, 1996). The production of green leaf biomass has an ideal contribution in release of important crop available nutrients through its decomposition and modifying the agricultural land either it is by improving physical, biological or chemical properties. Promising leguminous trees/shrubs improve soil fertility as source of nutrient for agricultural crops are being exploited in the alley cropping system (Chu et al., 2004). The biomass produced by Sesbania hedgerows has wider importance in the composition of important soil nutrients and increased yield in simultaneously cropping season. Similarly, Bekele (2007) reported in most parts of SSA, farmers use improved fallows as a strategy for improving soil fertility within a shorter timeperiod. Alley cropping is most effective at maintaining soil fertility on continuously cropped land.

Table 5. Analyzed soil physico-chemical parameters before experimentation.

\begin{tabular}{|c|c|c|c|c|c|c|c|c|c|c|}
\hline \multicolumn{7}{|c|}{ Soil parameters } & \multicolumn{4}{|c|}{ Soil texture (\%) } \\
\hline $\mathrm{pH}$ & $\% \mathrm{TN}$ & $\% \mathrm{OC}$ & $\mathrm{P}(\mathrm{ppm})$ & $\mathrm{K}(\mathrm{ppm})$ & $\mathrm{B}(\mathrm{ppm})$ & $\mathrm{SO} 4-\mathrm{S}$ & Clay & Silt & Sand & Class \\
\hline 5.70 & 0.11 & 1.33 & 15.65 & 74.12 & 0.45 & 10.96 & & & & \\
\hline S. ac & Md & $\mathrm{L}$ & Md & Md & Md & Md & 12 & 10 & 78 & $\begin{array}{l}\text { Sandy } \\
\text { loam }\end{array}$ \\
\hline
\end{tabular}

Source own data, 2017-2019

Where, Md (medium), L (low), S.ac (slightly acidic)

The average compositions of clay, silt and sand textural classification of the experimental area percentages were 12, 10 and 78, was classified as sandy loam. respectively. Thus according to USDA soil

Table 6. Analyzed soil physico-chemical properties under each legume shrub species.

\begin{tabular}{|llllllll|}
\hline Treatments & \multicolumn{7}{c|}{ Soil parameters } \\
\hline Cajanus cajan + maize & $\mathrm{pH}$ & \%OC & \%TN & P (ppm) & K (ppm) & B (ppm) & SO4-S \\
\hline Sesbania sesban + maize & 5.74 & 1.170 & 0.101 & 15.97 & 79.89 & 0.58 & $7.31^{\mathrm{B}}$ \\
\hline Maize with fertilizer & 5.74 & 1.400 & 0.120 & 23.98 & 90.78 & 0.61 & $19.74^{\mathrm{A}}$ \\
\hline Maize without fertilizer & 5.66 & 1.200 & 0.101 & 18.98 & 97.92 & 0.58 & $10.97^{\mathrm{AB}}$ \\
\hline Before planting & 5.71 & 1.091 & 0.094 & 15.65 & 74.12 & 0.45 & $10.96^{\mathrm{AB}}$ \\
\hline LSD & $\mathrm{NS}$ & $\mathrm{NS}$ & 0.04 & 11.64 & 60.02 & 0.45 & 12.30 \\
\hline CV (\%) & 2.88 & 15.19 & 15.29 & 23.44 & 25.04 & 33.25 & 41.86 \\
\hline
\end{tabular}

Source: Own data, 2017-2019 
Table 7. Correlation between the measured soil parameters.

\begin{tabular}{|c|c|c|c|c|c|c|c|}
\hline & $\mathrm{pH}$ & $\mathrm{OC}$ & TN & $\mathrm{P}$ & K & B & $\mathrm{SO}_{4}-\mathrm{S}$ \\
\hline $\mathrm{pH}$ & 1 & & & & & & \\
\hline $\mathrm{OC}$ & 0.469 & 1 & & & & & \\
\hline $\mathrm{TN}$ & 0.466 & $0.997^{*}$ & 1 & & & & \\
\hline $\mathrm{P}$ & -0.275 & 0.240 & 0.240 & 1 & & & \\
\hline $\mathrm{K}$ & -0.303 & 0.230 & 0.230 & $0.524^{*}$ & 1 & & \\
\hline B & -0.209 & -0.397 & -0.395 & -0.017 & -0.203 & 1 & \\
\hline $\mathrm{SO} 4-\mathrm{S}$ & -0.152 & 0.368 & 0.364 & 0.216 & -0.100 & 0.384 & 1 \\
\hline
\end{tabular}

Source own data, 2017-2019

Table 8. Leaf nutrient analyzed from hedgerow shrub species.

\begin{tabular}{|c|c|c|c|c|c|}
\hline \multirow[t]{2}{*}{ Species(treatments) } & \multicolumn{3}{|c|}{ Nutrients released } & \multirow[t]{2}{*}{ LBM kg ha-1 } & \multirow[t]{2}{*}{ LBM ton $\mathrm{ha}^{-1}$} \\
\hline & $\% \mathrm{~N}$ & $\% \mathrm{P}$ & $\% \mathrm{~K}$ & & \\
\hline Cajanus cajan & 3.65 & 0.47 & 4.18 & $3200^{b}$ & 3.200 \\
\hline Sesbania sesban & 4.71 & 0.59 & 4.31 & $11561^{\mathrm{a}}$ & 11.561 \\
\hline
\end{tabular}

Source own data, 2017-2019

Where: LMB (leaf biomass), ha ${ }^{-1}$ (per hectare), for $N$ o.3 $g$ of leaf sample used and $0.5 \mathrm{~g}$ was used for $P$ and $K$ analysis.

Table 9. Contribution of green biomass for nutrient release.

\begin{tabular}{|lcccc|} 
Shrub species & LBM ton ha ${ }^{-1}$ & N (from LBM) & P (from LBM) & K (from LBM) \\
\hline Cajanus cajan & 3.20 & $116.80 \mathrm{~kg}$ & $15.04 \mathrm{~kg}$ & $133.76 \mathrm{~kg}$ \\
\hline Sesbania sesban & 11.56 & $544.52 \mathrm{~kg}$ & $68.21 \mathrm{~kg}$ & $498.30 \mathrm{~kg}$ \\
\hline
\end{tabular}

Source own data, 2018-2019

Where: LMB (leaf biomass), ha ${ }^{-1}$ (per hectare), for $N$ o.3 $g$ of leaf sample used and $0.5 \mathrm{~g}$ was used for $P$ and $K$ analysis

\section{Relation between organic matter and organic carbon obtained from green biomass}

The present study result showed that the amount of organic matter depends on legume shrub species used in hedgerows intercropping practice and biomass produced by these species. Form the shrub species, $S$. sesban provides huge amount of organic matter and nitrogen concentration in comparison with $C$. cajan, these related with organic carbon and $\mathrm{C}: \mathrm{N}$ ratio at which the mineralization process determined. For instance the variation of $\mathrm{C}$ : $\mathrm{N}$ value for both species showed (Table 10) that the amount of carbon and nitrogen nutrients constituted in the organic biomass of the species. The C: $\mathrm{N}$ value described as 11.22 and 14.32 for $S$. sesban and C. cajan, respectively. Mineralization of organic matter depends on this critical parameters at which the process under taken. The result of the present study in line with previous studies of Aerts and de Caluwe (1997), Teklay et al. (2007) who reported the concentrations of nitrogen $(\mathrm{N})$, phosphorus $(\mathrm{P})$, and the ratios of $\mathrm{C} / \mathrm{N}$ are recognized as the main organic biomass quality variables controlling rates of decomposition. Mineralization process occurs faster at lower C: $\mathrm{N}$ ratio (high nitrogen) at which the conversion of organic minerals into in organic or mineral form and easily available for crop uptake.

Table 10. Analyzed value for organic matter, organic carbon and C: $\mathrm{N}$ ratio for each species.

\begin{tabular}{|c|c|c|}
\hline \multirow{2}{*}{ Parameters } & \multicolumn{2}{|c|}{ Shrub species used in hedgerows intercropping } \\
\hline & Sesbania sesban & Cajanus cajan \\
\hline$\% \mathrm{OM}$ & 90.92 & 89.90 \\
\hline$\% \mathrm{OC}$ & 52.86 & 52.27 \\
\hline$\% \mathrm{~N}$ & 4.71 & 3.65 \\
\hline C:N ratio & 11.22 & 14.32 \\
\hline In terms long term production & $\begin{array}{l}\text { Used for 10-11 production } \\
\text { season }\end{array}$ & $\begin{array}{c}\text { Used for } 2-3 \text { production } \\
\text { season }\end{array}$ \\
\hline
\end{tabular}

Source: own data, 2017- 2019

Where: OM (Organic Matter), OC (Organic Carbon), N (Nitrogen), and C: N (Carbon to Nitrogen ratio) 


\section{Maize crop production under alley cropping}

Alley cropping is an important farming practice carried on annual crops with legume hedgerow species, through which soil fertility improved and productivity increased. The grain yield of maize grown in alleys was influenced significantly $(\mathrm{P}<0.05)$ by nitrogen levels (Table 9). Maize yield production was maintained in alley cropping practice, affected with different beneficial nutrients contributed by organic biomass of hedgerow species. In the present study, maize grain yields was higher in Sesbania hedgerow intercropping than the other plots, significantly different from Pigeon pea plot (Table 10). Maize grain yield obtained from $C$. cajan hedgerow intercropping twice lower than that of $S$. sesban intercropping, this is due to the amount and nutrients released from pruned biomass produced from the hedgerow species. The trend in the order of $S$. sesban + maize > maize + fertilizer $>$ control (maize without IF) $>$ C. cajan + maize. The amount and release of nutrients determined by pruned biomass, its decomposition rate, type of hedgerow species, soil type and active soil microorganisms. Total biomass of maize crop grown on plots of $S$. sesban hedgerow had the highest value than the other plots. Grain yield of maize highly correlated with yield components like plant height, seed weight and total biomass, these factors have direct effect on grain yield (Table 11). The present study result in line with the findings of Naya et al. (2007), who reported inclusion of appropriate nitrogen fixing tree/shrub legumes in farming systems usually reduces $\mathrm{N}$ loss through leaching thereby maximizes yield from croplands. Similarly, Aihou et al. (1998) reported 107\% more maize yield in alley cropping on the degraded site. Maize yield improvement through alley cropping with different woody species has been reported in many countries (Chamshama et al., 1998; Tossah et al., 1998; Friday and Fownes, 2002).

Table 11. Maize yield and yield component parameters measured in alley cropping practices of hedgerow species.

\begin{tabular}{|lcccc|}
\multicolumn{1}{c}{ Treatments } & \multicolumn{4}{c|}{ Measured parameters } \\
& Ph in $\mathrm{m}$ & HSW in & TBM ton ha & GY in ton ha $^{-1}$ \\
\hline Cajanus cajan + maize & 2.12 & 33.81 & 13.99 & $2.62^{\mathrm{b}}$ \\
\hline Sesbania sesban + maize & 2.47 & 40.88 & 28.07 & $5.97^{\mathrm{a}}$ \\
\hline Maize with fertilizer & 2.34 & 36.50 & 19.34 & $4.49^{\text {ab }}$ \\
\hline Maize without fertilizer & 2.20 & 36.14 & 15.43 & $3.40^{\text {ab }}$ \\
\hline LSD & NS & NS & NS & 1.64 \\
\hline CV $(\%)$ & 6.10 & 12.61 & 28.67 & 24.65 \\
\hline
\end{tabular}

Source: own data, 2017- 2019

Where: Ph (plant height), HSW (hundred seed weight), TBM (total biomass), GY (grain yield)

Table 12. Pearson correlation results of yield components relation with maize grain yield.

\begin{tabular}{|lll|} 
Correlation factors(components & Grain yield & Significant \\
\hline Treatment & 0.062 & $0.85 \mathrm{Ns}$ \\
\hline Plant height & 0.960 & $0.0001^{*}$ \\
\hline Hundred seed weight & 0.610 & $0.02^{*}$ \\
\hline Total biomass & 0.970 & $0.0001^{*}$ \\
\hline
\end{tabular}

Source: own data, 2017- 2019

\section{Conclusion and Recommendation}

The results obtained showed that hedgerow intercropping improved the soil nutrients over the pre-planting. Particularly, S. sesban hedgerow plays an important role in improvement of soil nutrients; as well, it increased maize grain yield and compatible species under hedgerow intercropping. However, more plant nutrients were gradually built up in hedgerow plots than in the fertilizer and control plots. Therefore, pruned biomass of legume species incorporated into the soil under hedgerow intercropping reduced the rate of soil nutrient depletion and increased productive base of the soil through nutrient released during the decomposition of pruned biomass. From the present study, issues to be considered as future direction are hedgerow intercropping needs special attention towards the demonstration of the practice in appropriate form to stakeholders to sustain their agricultural production, integration of livestock component to improve the economic return of farm households and technical support should be provided through professional experts is important. S. sesban has good growth performance, huge leafy green biomass adheres with important soil nutrient 
composition in the study area, it is recommended as an important legume shrub to integrate on agricultural land with annual crops under hedgerow intercropping. This should be intensively demonstrated to sustain the agricultural production as an organic farming through integration of easily adapting, less competing with the companion crop, deep rooted and fast growing legume shrub species. Further research is important to determine rate of decomposing of pruned biomass, potential species should be identified having uniform growth performance and ideal to integrate with annual crops.

\section{Conflict of interest}

The authors declare that there is no conflict of interest regarding the publication of this article.

\section{Acknowledgements}

The authors acknowledge Southern Agricultural Research institute for financial support to conduct this experimentation and Jinka Agricultural Research center for its strong administrative facilitation by providing important inputs to handle the research accordingly. The collaboration of researchers in Natural Resource Research Directorate is highly appreciated. In addition, the intimate communications of farmhouse hold frequent field monitoring would be strongly acknowledged.

\section{References}

Abebe, T., Wiersum, K.F., Bongers, F.J.J.M. and Sterck, F. 2006. Diversity and dynamics in homegardens of southern Ethiopia. In: Tropical home gardens. Springer, Dordrecht. pp. 123-142.

https://doi.org/10.1007/978-1-4020-4948-4_8

Aerts, R. and de Caluwe, H. 1997. Nutritional and plant-mediated controls on leaf litter decomposition of Carex species. Ecol. 78(1): 244-260. https://doi.org/10.1890/00129658(1997)078[0244:NAPMCO]2.0.CO;2

Aihou, K., Sanginga, N., Vanlauwe, B., Lyasse, O., Diels, J. and Merckx, R. 1998. Alley cropping in the moist savanna of West-Africa: I. Restoration and maintenance of soil fertility on'terre de barre 'soils in Bénin Republic. Agrofor. $\quad$ Syst. 42(3): 213-227. https://doi.org/10.1023/A:1006114116095

Alegre, J.C. and Rao, M.R. 1996. Soil and water conservation by contour hedging in the humid tropics of Peru.Agric. Ecosyst. Environ. 57(1): 17-25.

https://doi.org/10.1016/0167-8809(95)01012-2

Assefa, A., Tadese, T. and Liben, M. 2013. Influence of time of nitrogen application on productivity and nitrogen use efficiency of rain-fed lowland rice (Oryza sativa L.) in the vertisols of Fogera Plain, northwestern Ethiopia. Ethiopian J. Sci. Tech. 6(1): 25-31.
Bekele, T.A. 2007. Profitable Agroforestry Innovations for Eastern Africa: Experience from 10 Agroclimatic Zones of Ethiopia, India, Kenya, Tanzania, and Uganda. Regional Land Management Unit. 388p.

Bray, R.H. and Kurtz, L.T. 1945. Determination of total, organic, and available forms of phosphorus in soils. Soil Sci.59(1): 39-46. https://doi.org/10.1097/00010694-194501000-00006

Chamshama, S.A.O., Mugasha, A.G., Kløvstad, A., Haveraaen, O. and Maliondo, S.M.S. 1998. Growth and yield of maize alley cropped with Leucaena leucocephala and Faidherbia albida in Morogoro, Tanzania.Agrofor. Syst. 40(3): 215-225.

https://doi.org/10.1023/A:1006025005441

Chu, G.X., Shen, Q.R. and Cao, J.L. 2004. Nitrogen fixation and $\mathrm{N}$ transfer from peanut to rice cultivated in aerobic soil in an intercropping system and its effect on soil $\mathrm{N}$ fertility. Plant Soil. 263: 17-27.

https://doi.org/10.1023/B:PLSO.0000047722.49160.9e

Day, P.R. 1965. Particle fractionation and particle-size analysis. Methods of Soil Analysis: Part 1 Physical and Mineralogical Properties, Including Statistics of Measurement and Sampling, 9.1, pp. 545567. https://doi.org/10.2134/agronmonogr9.1.c43

Evans, J., McNeill, A.M., Unkovich, M.J., Fettell, N.A. and Heenan, D.P. 2001. Net nitrogen balances for cool-season grain legume crops and contributions to wheat nitrogen uptake: a review. Australian J. Exptl. Agric. 41(3): 347-359. https://doi.org/10.1071/EAooo36

Friday, J.B. and Fownes, J.H. 2002. Competition for light between hedgerows and maize in an alley cropping system in Hawaii, USA. Agrofor. Syst. 55(2): 125-137. https://doi.org/10.1023/A:1020598110484

Hartemink, A.E., Buresh, R.J., Van Bodegom, P.M., Braun, A.R., Jama, B. and Janssen, B.H. 2000. Inorganic nitrogen dynamics in fallows and maize on an Oxisol and Alfisol in the highlands of Kenya. Geoderma. 98(1-2): 11-33.

https://doi.org/10.1016/Soo16-7061(oo)ooo72-o

Jordan, C.F. 2004. Organic farming and agroforestry: Alley cropping for mulch production for organic farms of southeastern United States. Agrofor. Syst. 61(1-3): 79-90. https://doi.org/10.1023/B:AGFO.0000028991.86647.35

Kang, B.T., Reynolds, L. and Atta-Krah, A.N.1990. Alley farming. In: Advances in Agronomy. Academic Press. Vol. 43, pp. 315-359.

https://doi.org/10.1016/Soo65-2113(o8)60481-2

Kjeldahl, J. 1883. A new method for the estimation of nitrogen in organic compounds. Zeitschrift für Analytische Chemie. 22(1): 366-382.

http://dx.doi.org/10.1007/BF01338151

Kwesiga, F.R., Franzel, S., Place, F., Phiri, D. and Simwanza, C.P. 1999. Sesbania sesban 
improved fallows in eastern Zambia: Their inception, development and farmer enthusiasm. Agrofor. Syst. 47(1-3): 49-66. https://doi.org/10.1023/A:1006256323647

Maiti, S.K. and Ghose, M.K. 2005. Ecological restoration of acidic coalmine overburden dumps- an Indian case study. Land Contamin. Reclam. 13(4): 361-369. https://doi.org/10.2462/09670513.637

Miah, M.G., Garrity, D.P.N. and Aragon, M.L. 1997. Effect of legume trees on soil chemical properties under agroforestry system. Ann. Bangladesh Agric. 7(2): 95-100.

Miller, R.W. and Donahue, R.L. 1990. Soils: an introduction to soils and plant growth (No. Ed. 6). Prentice-Hall International Inc. 667p.

Nair, P.R., Buresh, R.J., Mugendi, D.N. and Latt, C.R. 1999. Nutrient cycling in tropical agroforestry systems: myths and science. Agro Forestry in Sustainable Agricultural Systems. CRC Press, Boca Raton, FL, USA. pp. 1-31.

Naya, L., Ladrera, R., Ramos, J., González, E.M., Arrese-Igor, C., Minchin, F.R. and Becana, M. 2007. The response of carbon metabolism and antioxidant defenses of alfalfa nodules to drought stress and to the subsequent recovery of plants. Plant Physiol. 144(2): 1104-1114. https://doi.org/10.1104/pp.107.099648

Nelson, D.W. and Sommers, L.E. 1996. Total carbon, organic carbon, and organic matter. Methods of Soil Analysis: Part 3 Chemical Methods, 5.3. pp. 961-1010. https://doi.org/10.2136/sssabookser5.3.c34
Parysow, P., Wang, G., Gertner, G. and Anderson, A.B. 2001. Assessing uncertainty of erodibility factor in national cooperative soil surveys: a case study at Fort Hood, Texas. $J$. Soil Water Conserv. 56(3): 207-211.

Richards, I.G., Palmer, J.P. and Barratt, P.A. 1993. The reclamation of former coalmines and steelworks. Volume 56, $1^{\text {st }}$ edn. Elsevier Science. 717p.

Sjögren, H., Shepherd, K.D. and Karlsson, A. 2010. Effects of improved fallow with Sesbania sesban on maize productivity and Striga hermonthica infestation in Western Kenya. J. Forestry Res. 21(3): 379-386. https://doi.org/10.1007/s11676-010-0085-0

Teklay, T., Nordgren, A., Nyberg, G. and Malmer, A. 2007. Carbon mineralization of leaves from four Ethiopian agroforestry species under laboratory and field conditions. Appl. Soil Ecol. 35(1):193-202. https://doi.org/10.1016/j.apsoil.2006.04.002

Tossah, B.K., Zamba, D.K., Vanlauwe, B., Sanginga, N., Lyasse, O., Diels, J. and Merckx, R. 1998. Alley cropping in the moist savanna of West-Africa: II. Impact on soil productivity in a North-to-South transect in Togo. Agrofor. Syst. 42(3): 229-244. https://doi.org/10.1023/A:1006124317003

USDA. 2012. World agricultural supply and demand estimates. http://usda.mannlib.cornell. edu/reports/waobr/wasde-bb.

Young, A. 1999. Agroforestry for soil management (No. Ed. 2). CAB International. 320p. 